\title{
Status of Geoscientific Site Evaluations for Canada's Deep Geological Repository for Used Nuclear Fuel
}

S. HiRSCHORn, A. BLyTh, A. PARMENTER, M. SANCHEZ-RICO CASTEJON AND A. VORAUER

Nuclear Waste Management Organization, Toronto, Canada, M4T 2S3 (*correspondence: shirschorn@nwmo.ca)

The Nuclear Waste Management (NWMO) is responsible for implementing, collaboratively with Canadians and Indigenous people, Canada's Plan for the safe, long-term management of used nuclear fuel. Made up of engineers, technical experts, social scientists and engagement professionals, the NWMO is working to implement Canada's plan, in a manner that protects both people and the environment. Canada's plan calls for containment and isolation of used nuclear fuel in a deep geological repository, which is made up of a series of natural and engineered barriers. This facility will be located in an area with informed, willing hosts and a suitable rock formation. The NWMO is on track to identify a single, preferred location for this facility by approximately 2023 .

This paper will provide a look at what the NWMO has accomplished and what is ahead, including some of the challenges facing the organization. The presentation will describe, too, the NWMO's technological and social innovations as it has engaged municipalities, residents, and First Nations and Metis communities across the country to identify a permanent site. 